\title{
BIO-CHEMICAL MANAGEMENT OF GREY BLIGHT OF MUSTARD THROUGH SELECTED BOTANICALS AND CHEMICALS
}

\author{
M.H. Kabir, Y.A. Ara, A.J.M. Moin Uddin, M.A. Islam and M.B. Hossain* \\ Department of Plant Pathology \\ Sher-e-Bangla Agricultural University, Dhaka, Bangladesh
}

\begin{abstract}
Grey Blight of Mustard caused by Alternaria sp. is one of the most important diseases of oil producing crop of Bangladesh causing heavy yield loss which is approximately $30-40 \%$. In this study the effectiveness of selected botanicals, chemicals and their combined effects were assessed to manage this disease. Fourteen treatments including control were evaluated viz. $\mathrm{T}_{1}=$ Control, $\mathrm{T}_{2}=$ Trichoderma harzianum suspension, $\mathrm{T}_{3}=$ Autostin $50 \mathrm{WDG}, \mathrm{T}_{4}=$ Rovral $50 \mathrm{WP}, \mathrm{T}_{5}=$ Dithane $\mathrm{M}$ $45, T_{6}=$ Amistar Top $325 \mathrm{SC}, \mathrm{T}_{7}=$ Neem leaf extract, $\mathrm{T}_{8}=$ Allamanda leaf extract, $T_{9}=$ Lantana leaf extract, $T_{10}=$ Datura leaf extract, $T_{11}=$ Neem leaf extract + Rovral, $T_{12}=$ Datura leaf extract + Amistar Top, $T_{13}=$ Lantana leaf extract + Dithane $\mathrm{M}-45$ and $\mathrm{T}_{14}=$ Allamanda leaf extract + Autostin. Among the chemicals, the lowest disease incidence (\%), disease severity (\%), disease severity index (\%) and pod infection (\%) was found in $\mathrm{T}_{5}$ treatment (Dithane $\mathrm{M}-45$ ) which was $55.91 \%, 22.09 \%$, $32.16 \%$ and $6.72 \%$, respectively, at 70 and 75 DAS, respectively. While among the botanicals, the lowest disease incidence (\%), disease severity $(\%)$, disease severity index (\%) and pod infection (\%) was found in $\mathrm{T}_{9}$ treatment (Lantana leaf extract) which was $65.05 \%, 28.89 \%, 37.96 \%$ and $13.79 \%$, respectively, at 70 and 75 DAS, respectively. In case of combined treatments, the lowest disease incidence (\%), disease severity $(\%)$, disease severity index (\%) and pod infection (\%) was found in $T_{13}$ treatment (Lantana leaf extract + Dithane M-45) which was $59.14 \%$, $26.32 \%, 38.20 \%$ and $12.30 \%$, respectively, at 70 and 75 DAS respectively. While the highest disease incidence (\%), disease severity $(\%)$, disease severity index (\%) and pod infection (\%) was found in $\mathrm{T}_{1}$ treatment (Control) which was $79.20 \%, 37.54 \%, 67.38 \%$ and $34.63 \%$, respectively, 70 and 75 DAS, respectively. Among the treatments yield and yield attributers were found better in $T_{5}$ (Dithane M-45), $T_{9}$ (Lantana leaf extract) and $T_{13}$ (Lantana leaf extract + Dithane M-45). From the results on different parameters studied, the treatment Lantana leaf
\end{abstract}

\footnotetext{
* Corresponding Author: dr.mbhossain@sau.edu.bd
} 
extract $\left(T_{9}\right)$, Dithane $M-45\left(T_{5}\right)$ and their combined treatment $\left(T_{13}\right)$ can be used for management of grey blight mustard after few field trialing in consecutive year.

Keywords: Mustard, Alternaria blight, Bio-chemical management, combined effects, severity index.

\section{INTRODUCTION}

Mustard (Brassica spp.) is the major oil seed crop of Bangladesh yielding $36.83 \%$ of total oilseed production from $64.6 \%$ of the total area coverage (BBS, 2020). At present about 0.31 million hectares of land are covered to mustard cultivation in Bangladesh with yield of mustard seed in order of 0.35 million tons per year (BBS, 2020). It is cultivated almost all over the world. The average production of the world is $2.04 \mathrm{t} \mathrm{ha}^{-1}$ (FAO, 2015), whereas in Bangladesh is $0.5 \mathrm{t} \mathrm{ha}^{-1}$. It is a cold loving crop that is mainly cultivated in Rabi season in Bangladesh. The weather condition suitable for this crop is low temperature and scanty rainfall. Many factors are associated with the poor yield of mustard in Bangladesh. Diseases have been identified as one of the major factors (Ahmed, 1992). It suffers from about 14 diseases (fungus, 9, virus, 2, bacteria, 1, nematode, 1 and parasitic plant, 1) in Bangladesh (Anonymous, 2007). Among these diseases grey leaf blight, downy mildew and the parasitic plant are the most important (Anonymous, 2007). Grey leaf blight caused by Alternaria brassicae/ Alternaria brassicicola is widely distributed and the most serious and devastating disease of rapeseed-mustard. Most of the Alternaria species are saprophytes and ubiquitous in the environment (Simmons, 1992). The pathogens are greatly influenced by weather with the highest disease incidence reported in wet seasons and areas with relatively heavy rainfall (Meena et al., 2010). The characteristic symptom is the development of circular spots on leaves and pods with concentric ring. Later on, spots coalesce and ultimately the leaves become blighted. The disease may cause $25 \%$ yield reduction at severe condition of infection (Anonymous, 2001).

Protection of seedpod from Alternaria blight infection should, therefore, be the most important aim for higher yield of mustard. The most economical and environmentally safe method of controlling the disease is use of resistant varieties. Information on resistance source is not available, although some sort of tolerance may be available. There is no information available on the resistance sources. Chemicals are being successfully used in controlling the disease (Meah et al., 1988; Howlider et al., 1985). But using excessive chemicals is discouraged as it is harmful for the environment and the residual effect can cause decay to human health. Non-chemical methods of disease control may include use of biological agents, botanicals, adjustment in cultural practices etc.

Different medicinal leaf extract which has antifungal effect such as neem, alamanda, lantana, datura etc can be used as botanicals and Trichoderma harzianum can be used 
as biological agent. They can be successfully applied as an ecofriendly alternative of chemicals for the management of grey blight of mustard. Using the botanicals as foliar spray and biological agent as soil treatment can successfully control the pathogen attack. The combined treatment of chemicals and botanicals also shows satisfying result which also reduces the use of chemicals only in case of grey blight disease management in mustard. The purpose of this study was to find out the most effective botanical, chemical or their combined treatment to manage the disease in the possibly most effective way.

\section{MATERIALS AND METHODS}

\section{Identification of the disease and evaluating the efficacy of selected bio-chemicals}

Identification of the disease was done mainly through visual observation of typical symptoms of grey blight like development of circular spots on leaves \& pods with concentric ring and elongated lesion on stem. Later on spots coalesce and ultimately the leaves become blighted. The disease incidence (\%), disease severity $(\%)$ and disease severity index $(\%)$ of grey blight of Mustard was recorded by counting infected plants, infected leaves and estimating infected leaf area at 50, 60 and 70 days after sowing (DAS). The pod infection (\%) was recorded by counting the infected pods at 55, 65 and 75 (DAS). To evaluate the efficacy of the selected bio-chemical treatments for disease management, the following parameters were undertaken: number of infected plant/plot, number of infected leaf/plant, infected leaf area/ leaf, number of infected pod/ plant, fresh yield/plot $\left(\mathrm{kg} \mathrm{ha}^{-1}\right)$, dry yield/plot $\left(\mathrm{kg} \mathrm{ha}^{-1}\right)$, fresh grain weight (gm/plot), dry grain weight (gm/plot) and 1000-seed weight/plot (gm).

\section{Collection and preparation of selected Bio-Chemicals}

Neem leaf, Allamanda leaf, Lantana leaf and Datura leaves were used as botanicals. Botanicals were collected from Sher-e-Bangla Agricultural University, Dhaka. Fresh leaves were collected and weighed $100 \mathrm{gm}$ per botanical. The leaves were washed and chopped into small pieces. To prepare the extract the chopped leaves were blended with electric blender and sieved through strainer. Hundred ml leaf extract of each botanical was added into one litre distilled water maintaining ratio 1:10 for foliar spray. Autostin (Carbendazim), Dithane M-45(Mancozeb), Amistar Top (Azoxystrobin+Difenoconazol) and Rovral (Ipridione) were selected as chemical fungicides maintaining dose $0.3 \%, 0.3 \%, 0.1 \%$ and $0.2 \%$, respectively. The chemicals were handled maintaining proper precautions through wearing hand gloves, goggles, face mask and apron. Each chemical was weighed according to the mentioned dose and carefully incorporated into water to prepare the spray solution. The Trichoderma harzianum suspension was prepared @ $20 \mathrm{ml} / \mathrm{liter}$. The suspension was measured and mixed thoroughly with water then preserved in cool temperature and darkness. 


\section{Calculation of diseases related parameters}

The disease incidence and severity of grey blight was recorded by counting the infected plants on the basis of symptoms appearance, and by counting the infected leaves per plant, respectively. The disease severity index was calculated by measuring the infected leaf and the pod infection by counting the spots on infected pod. For collection data on above mentioned parameters, in total fifteen (15) plants per plot $\left(6 \mathrm{~m}^{2}\right)$ were selected randomly and red tagged was used for indication. The selected plants were inspected every morning to note the appearance of the symptoms starting from the following day of sowing.

Percent disease incidence was calculated by the following formula:

$\%$ Disease Incidence $=$ -

Percent disease severity was calculated by the following formula:

Number of infected leaf per plant

$\%$ Disease Severity = ----------- X 100

Number of total inspected leaf per plant

Percent disease severity index was calculated by the following formula:

Leaf area infected

$\%$ Disease Severity Index = ------------------------ X 100

Total leaf area

Percent pod infection was calculated by the following formula:

Number of infected pod per plant

$\%$ Pod Infection = ------------------ X 100

Total number of pod per plant

\section{Statistical analysis}

The data were statistically analyzed using computer based software Statistix-10. Treatment means were compared by DMRT (Duncan's Multiple Range Test). To determine the relationship between percent disease incidences, severity, severity index and pod infection with yield for each of the treatments correlation and regression study were done.

\section{RESULTS AND DISCUSSION}

Effect of different treatments on disease incidence (\%) at 50, 60 and 70 days after sowing

The effect of selected treatments on percent disease incidence for grey blight of mustard was recorded and the disease incidence ranged from 43.0-59.02\%, 45.16$69.35 \%$ and $55.91-79.20 \%$ at 50, 60 and 70 DAS, respectively (Table 1). From the 
study, it was found that among treatments, the lowest disease incidence was recorded in $\mathrm{T}_{5}$ (Dithane $\mathrm{M}-45$ ) and the highest in $\mathrm{T}_{1}$ (control) at all observation. Among the chemical treatments, the lowest disease incidence was found in $\mathrm{T}_{5}$ (Dithane M-45) followed by $\mathrm{T}_{3}$ (Autostin) where the highest disease incidence was recorded in $\mathrm{T}_{4}$ (Rovral). Among the botanical treatments, the lowest disease incidence was found in $\mathrm{T}_{9}$ (Lantana leaf extract) followed by $\mathrm{T}_{10}$ (Datura leaf extract) while the highest disease incidence was recorded in $\mathrm{T}_{7}$ (Neem leaf extract). Among the combined treatments, the highest disease incidence was recorded in $\mathrm{T}_{11}(\mathrm{Neem}+\mathrm{Rovral})$, where the lowest disease incidence was found in $T_{13}$ (Lantana+ Dithane M-45). From these results it was also revealed that the $\mathrm{T}_{2}$ treatment (Trichoderma harzianum suspension) was showed the moderate disease incidence and gave best performance for controlling grey blight disease of mustard. Prasad et al. (2003) conducted an experiment to determine the losses due to Alternaria blight (Alternaria brassicae) under protected and unprotected conditions. The protected plots were sprayed with $0.25 \%$ mancozeb starting from 40 days after sowing and 3 subsequent sprays at 15 day intervals. The disease appeared 45 days after sowing. Treatment with mancozeb reduced disease incidence in all the genotypes. There was a 72.6 and $59.0 \%$ reduction in disease severity for RN 490 and the lowest disease intensity (17.8 and 16.1\%) was recorded in the protected plots compared to the unprotected plots (39.6 and 32.5\%) in both the years. Singh and Singh (2006) conducted a field experiment to develop spray schedule(s) for the management of blight caused by Alternaria brassicae and A. brassicicola, and white rust caused by Albugo candida appling three consecutive sprays of Mancozeb 75 WP $(0.2 \%)$ at fortnightly intervals, beginning at the disease initiation resulted in the lowest leaf blight incidence and pod blight intensity.

\section{Effect of different treatments on disease severity (\%) at 50,60 and 70 DAS}

The data recorded on the effect of selected treatments on percent disease severity for grey blight of mustard and ranged from $11.89-16.84 \%, 18.49-21.77 \%$ and 22.09 $37.54 \%$ at 50, 60 and 70 DAS, respectively (Table 2). It was observed that the treatments varied significantly from each and other. Among the selected treatments, the lowest disease severity was found in $\mathrm{T}_{13}$ (Lantana + Dithane M-45) at 50 DAS but less disease severity was found in $\mathrm{T}_{2}(18.49 \%, 26.08 \%$, Trichoderma harzianum suspension) at 60 and 70 DAS and the highest disease severity was recorded in $\mathrm{T}_{1}$ (control) at all observations. Among the chemical treatments, the lowest disease severity was recorded in $\mathrm{T}_{5}$ (Dithane $\mathrm{M}-45$ ) at all observations. The highest disease severity was recorded in $\mathrm{T}_{4}(15.26 \%$ Rovral $)$ at $50 \mathrm{DAS}$, but at $60 \mathrm{DAS}$, the highest disease severity was found in $\mathrm{T}_{3}(20.92 \%$, Autostin) and at 70 DAS it was higher in $\mathrm{T}_{6}(29.27 \%$, Amistar top). Among the botanical treatments, the lowest disease severity was recorded in $\mathrm{T}_{9}$ (Lantana leaf extract, $12.57 \%, 19.44 \%$ and $28.89 \%$,) at all observations and the highest disease severity was found in $\mathrm{T}_{8}$ (Allamanda leaf extract, $12.99 \%, 20.21 \%$ at 50, 60 DAS. But at 70 DAS, the highest disease severity was found in $\mathrm{T}_{7}$ (Neem leaf extract, $34.37 \%$ ). Among the combined treatments, the 
lowest disease severity was found in $\mathrm{T}_{13}$ (Lantana + Dithane M-45) at all observations and the highest disease severity was recorded in $\mathrm{T}_{11}(14.42 \%, 32.01 \%)$ at 50 and 70 DAS, but it was found higher in $\mathrm{T}_{12}$ (Datura + Amistar top, 20.74\%) at 60 DAS. Results are also agreed with previous research reports. Chattopadhyay and Bagchi (1994) reported that the lowest severity and the highest yields were obtained following four foliar sprays with Mancozeb $(0.2 \%)$ at intervals of 15 days, starting from 30 days after sowing. Three sprays at 45,60 and 75 days after sowing gave the highest benefit ratios (3.9 and 3.88).

Table 1. Disease incidence (\%) under different treatments at 50,60 and 70 DAS

\begin{tabular}{lccc}
\hline & \multicolumn{3}{c}{ Disease incidence (\%) } \\
\cline { 2 - 4 } Treatments & 50 DAS & 60 DAS & 70 DAS \\
\hline $\mathrm{T}_{1}$ (Control) & $59.02^{\mathrm{a}}$ & $69.35^{\mathrm{a}}$ & $79.20^{\mathrm{a}}$ \\
$\mathrm{T}_{2}$ (Trichoderma harzianum suspension) & $47.29^{\mathrm{cd}}$ & $52.69^{\mathrm{bcd}}$ & $63.63^{\mathrm{bcd}}$ \\
$\mathrm{T}_{3}$ (Autostin 50 WDG) & $47.31^{\mathrm{cd}}$ & $52.60^{\mathrm{bcd}}$ & $56.63^{\mathrm{d}}$ \\
$\mathrm{T}_{4}$ (Rovral 50 WP) & $51.34^{\mathrm{abcd}}$ & $56.45^{\mathrm{abcd}}$ & $67.92^{\mathrm{abcd}}$ \\
$\mathrm{T}_{5}$ (Dithane M-45) & $43.00^{\mathrm{d}}$ & $45.16^{\mathrm{d}}$ & $55.91^{\mathrm{d}}$ \\
$\mathrm{T}_{6}$ (Amistar Top 325 SC) & $49.20^{\mathrm{bcd}}$ & $53.76^{\mathrm{bcd}}$ & $61.47^{\mathrm{bcd}}$ \\
$\mathrm{T}_{7}$ (Neem leaf extract) & $56.83^{\mathrm{ab}}$ & $56.99^{\mathrm{abcd}}$ & $73.48^{\mathrm{ab}}$ \\
$\mathrm{T}_{8}$ (Allamanda leaf extract) & $54.32^{\mathrm{abc}}$ & $67.20^{\mathrm{ab}}$ & $72.40^{\mathrm{abc}}$ \\
$\mathrm{T}_{9}$ (Lantana leaf extract) & $46.81^{\mathrm{cd}}$ & $51.06^{\mathrm{cd}}$ & $65.05^{\mathrm{bcd}}$ \\
$\mathrm{T}_{10}$ (Datura leaf extract) & $50.91^{\mathrm{abcd}}$ & $54.30^{\mathrm{bcd}}$ & $67.64^{\mathrm{abcd}}$ \\
$\mathrm{T}_{11}$ (Neem leaf extract+ Rovral) & $57.55^{\mathrm{ab}}$ & $60.21^{\mathrm{abc}}$ & $68.18^{\mathrm{abcd}}$ \\
$\mathrm{T}_{12}$ (Datura leaf extract + Amistar Top) & $51.54^{\mathrm{abcd}}$ & $56.99 \mathrm{abcd}$ & $67.70^{\mathrm{abcd}}$ \\
$\mathrm{T}_{13}$ (Lantana leaf extract + Dithane M- 45) & $49.41^{\mathrm{bcd}}$ & $55.73^{\mathrm{abcd}}$ & $59.14^{\mathrm{cd}}$ \\
$\mathrm{T}_{14}$ (Allamanda leaf extract + Autostin) & $54.84^{\mathrm{abc}}$ & $61.82^{\mathrm{abc}}$ & $67.02^{\mathrm{abcd}}$ \\
$\mathrm{CV}$ (\%) & 10.64 & 15.66 & $12.44^{\mathrm{ab}}$ \\
\hline
\end{tabular}


Table 2. Disease severity (\%) under different treatments at 50, 60 and 70 DAS

\begin{tabular}{|c|c|c|c|}
\hline \multirow{2}{*}{ Treatments } & \multicolumn{3}{|c|}{ Disease severity (\%) } \\
\hline & $50 \mathrm{DAS}$ & $60 \mathrm{DAS}$ & 70 DAS \\
\hline $\mathrm{T}_{1}$ (Control) & $16.84^{\mathrm{a}}$ & $21.77^{\text {a }}$ & $37.54^{\mathrm{a}}$ \\
\hline $\mathrm{T}_{2}$ (Trichoderma harzianum suspension) & $12.72^{\mathrm{cd}}$ & $18.49^{\mathrm{d}}$ & $26.08^{b c d}$ \\
\hline $\mathrm{T}_{3}$ (Autostin $\left.50 \mathrm{WDG}\right)$ & $13.82^{\mathrm{bcd}}$ & $20.92^{\mathrm{ab}}$ & $23.83^{\mathrm{cd}}$ \\
\hline $\mathrm{T}_{4}($ Rovral $50 \mathrm{WP})$ & $15.26^{\mathrm{ab}}$ & $20.20^{\text {abcd }}$ & $26.14^{\mathrm{bcd}}$ \\
\hline $\mathrm{T}_{5}$ (Dithane M-45) & $12.77^{\mathrm{cd}}$ & $19.17^{\mathrm{bcd}}$ & $22.09^{\mathrm{d}}$ \\
\hline $\mathrm{T}_{6}$ (Amistar Top $325 \mathrm{SC}$ ) & $13.30^{\mathrm{bcd}}$ & $20.29^{\text {abcd }}$ & $29.27^{\text {abcd }}$ \\
\hline $\mathrm{T}_{7}$ (Neem leaf extract) & $12.63^{\mathrm{cd}}$ & $19.50^{\mathrm{bcd}}$ & $34.37^{\mathrm{ab}}$ \\
\hline $\mathrm{T}_{8}$ (Allamanda leaf extract) & $12.99^{\mathrm{cd}}$ & $20.21^{\text {abcd }}$ & $32.84^{\mathrm{abc}}$ \\
\hline $\mathrm{T}_{9}$ (Lantana leaf extract) & $12.57^{\mathrm{cd}}$ & $19.44^{\mathrm{bcd}}$ & $28.89^{\mathrm{abcd}}$ \\
\hline $\mathrm{T}_{10}$ (Datura leaf extract) & $12.73^{\mathrm{cd}}$ & $20.05^{\text {abcd }}$ & $29.44^{\mathrm{abcd}}$ \\
\hline $\mathrm{T}_{11}$ (Neem leaf extract+ Rovral) & $14.42^{\mathrm{bc}}$ & $20.10^{\text {abcd }}$ & $32.01^{\mathrm{abc}}$ \\
\hline $\mathrm{T}_{12}$ (Datura leaf extract + Amistar Top) & $13.75^{\mathrm{bcd}}$ & $20.74^{\mathrm{abc}}$ & $30.67^{\mathrm{abcd}}$ \\
\hline $\mathrm{T}_{13}($ Lantana leaf extract + Dithane M- 45$)$ & $11.89^{\mathrm{d}}$ & $18.66^{\mathrm{cd}}$ & $26.32^{\mathrm{bcd}}$ \\
\hline $\mathrm{T}_{14}$ (Allamanda leaf extract + Autostin) & $12.97^{\mathrm{cd}}$ & $19.73^{\mathrm{abcd}}$ & $27.17^{\mathrm{bcd}}$ \\
\hline $\mathrm{CV}(\%)$ & 9.55 & 6.44 & 19.79 \\
\hline
\end{tabular}

Effect of different treatments on disease severity index (\%) at 50, 60 and 70 DAS

The effect of selected treatments on percent disease severity index for grey blight of mustard was estimated and ranged from 18.40-43.45\%, 27.87-49.35\%, 32.16-67.38\% at 50, 60 and 70 DAS, respectively (Table 3). Among the set treatments, minimum disease severity index was recorded in $\mathrm{T}_{2}$ (Trichoderma harzianum suspension, $18.40 \%$ ) followed by $\mathrm{T}_{5}$ (Dithane M-45, 19.19\%) at $50 \mathrm{DAS}$, but at 60 and $70 \mathrm{DAS}$, the lowest disease severity index was found in $\mathrm{T}_{5}$ (Dithane M-45) and maximum was recorded in control plot $\left(\mathrm{T}_{1}\right)$ at all observations. Among the chemical treatments, the lowest disease severity index was recorded in $\mathrm{T}_{5}$ (Dithane M-45) at all observations and the highest disease was found in $\mathrm{T}_{3}(28.78 \%$, Autostin) at 50 DAS while the highest in $\mathrm{T}_{4}(41.60 \%$ and $47.74 \%)$ at 60 and $70 \mathrm{DAS}$, respectively. In case of botanical treatments, the lowest disease severity index was found in $\mathrm{T}_{9}$ (Lantana leaf extract) at all observations and the highest disease severity index was recorded in $\mathrm{T}_{8}$ (Allamanda leaf extract) at 50 DAS but at 60 and 70 DAS, disease severity index was found higher in $\mathrm{T}_{7}\left(34.23 \%\right.$, Neem leaf extract) and $\mathrm{T}_{10}(48.45 \%$, Datura leaf extract). Among the combined treatments, the lowest disease severity index was found in $\mathrm{T}_{13}$ (Lantana+ Dithane M-45) at all observations. The highest disease severity index was recorded in $\mathrm{T}_{12}$ (Datura + Amister top) at $50 \mathrm{DAS}$, but at 60 and $70 \mathrm{DAS}$, it was found higher in $\mathrm{T}_{11}$ 
(Neem+ Rovral, 35.38\% and 49.10\% respectively). Results are also agreed with reported results regarding the disease severity index $(\%) /$ leaf area diseased (\% LAD) of mustard. Alam (2007) reported that the effect of different treatments on leaf area diseased (\% LAD) was found to be significant at different days after sowing (DAS) in response to the application of different chemicals fungicides and botanicals. Percent leaf area diseases (LAD) of mustard (SAU Sarisha-1) increased gradually with the advancement of crop growth. At 85 DAS, the highest percent leaf area diseased $(18.45 \%)$ was found at $\mathrm{T}_{1}$ (control) treatment and the lowest leaf area diseased $(2.59 \%)$ was recorded from the Rovral treated plots followed by Allamanda, Dithane M-45, Bavistin, Ridomil MZ-72 and Garlic treated plots.

Table 3. Disease severity index (\%) under different treatments at 50, 60 and 70 DAS

\begin{tabular}{lccc}
\hline \multirow{2}{*}{ Treatments } & \multicolumn{3}{c}{ Disease severity index (\%) } \\
\cline { 2 - 4 } & 50 DAS & 60 DAS & 70 DAS \\
\hline $\mathrm{T}_{1}$ (Control) & $43.45^{\mathrm{a}}$ & $49.35^{\mathrm{a}}$ & $67.38^{\mathrm{a}}$ \\
$\mathrm{T}_{2}$ (Trichoderma harzianum suspension) & $18.40^{\mathrm{d}}$ & $30.38^{\mathrm{bc}}$ & $46.50^{\mathrm{bcd}}$ \\
$\mathrm{T}_{3}$ (Autostin 50 WDG) & $28.78^{\mathrm{bc}}$ & $36.30^{\mathrm{bc}}$ & $44.58^{\mathrm{bcd}}$ \\
$\mathrm{T}_{4}$ (Rovral 50 WP) & $26.63^{\mathrm{bcd}}$ & $41.60^{\mathrm{ab}}$ & $47.74^{\mathrm{bc}}$ \\
$\mathrm{T}_{5}$ (Dithane M-45) & $19.19^{\mathrm{cd}}$ & $27.87^{\mathrm{c}}$ & $32.16^{\mathrm{e}}$ \\
$\mathrm{T}_{6}$ (Amistar Top 325 SC) & $24.20^{\mathrm{bcd}}$ & $32.40^{\mathrm{bc}}$ & $39.23^{\mathrm{cde}}$ \\
$\mathrm{T}_{7}$ (Neem leaf extract) & $29.09^{\mathrm{bc}}$ & $34.23^{\mathrm{bc}}$ & $45.49^{\mathrm{bcd}}$ \\
$\mathrm{T}_{8}$ (Allamanda leaf extract) & $29.90^{\mathrm{b}}$ & $30.50^{\mathrm{bc}}$ & $44.74^{\mathrm{bcd}}$ \\
$\mathrm{T}_{9}$ (Lantana leaf extract) & $27.84^{\mathrm{bcd}}$ & $28.71^{\mathrm{bc}}$ & $37.96^{\mathrm{de}}$ \\
$\mathrm{T}_{10}$ (Datura leaf extract) & $28.08^{\mathrm{bcd}}$ & $32.76^{\mathrm{bc}}$ & $48.45^{\mathrm{bc}}$ \\
$\mathrm{T}_{11}$ (Neem leaf extract+ Rovral) & $30.16^{\mathrm{b}}$ & $35.38^{\mathrm{bc}}$ & $49.10^{\mathrm{b}}$ \\
$\mathrm{T}_{12}$ (Datura leaf extract + Amistar Top) & $32.81^{\mathrm{b}}$ & $33.85^{\mathrm{bc}}$ & $41.22^{\mathrm{bcde}}$ \\
$\mathrm{T}_{13}$ (Lantana leaf extract + Dithane M- 45) & $25.59^{\mathrm{bcd}}$ & $28.80^{\mathrm{bc}}$ & $38.20^{\mathrm{de}}$ \\
$\mathrm{T}_{14}$ (Allamanda leaf extract + Autostin) & $28.98^{\mathrm{bc}}$ & $34.01^{\mathrm{bc}}$ & $45.20^{\mathrm{bcd}}$ \\
$\mathrm{CV}$ (\%) & 21.94 & 22.66 & 12.65 \\
\hline
\end{tabular}

\section{Effect of different treatments on pod infection (\%) at 55, 65 and 75 DAS}

The effect of selected treatments on percent pod infection was recorded and ranged from $0.65-2.97 \%, 1.73-7.25 \%$ and $6.72-34.63 \%$ at 55, 65 and 75 DAS (Table 4), respectively. From the study, it was recorded that among set treatments, the lowest pod infection was found in $\mathrm{T}_{5}$ (Dithane M-45) where the highest was recorded in $\mathrm{T}_{1}$ (Control) at all observations. Among the chemical treatments, Dithane M-45 $\left(\mathrm{T}_{5}\right)$ was gave the best result, which was statistically similar with $\mathrm{T}_{6}$ (Amistar top) and $\mathrm{T}_{4}$ (Rovral). Among the botanical treatments, the lowest pod infection was found in $\mathrm{T}_{9}$ 
(Lantana leaf extract) at 55 and 75 DAS whereas it was recorded the lowest in $\mathrm{T}_{8}$ (Allamanda leaf extract) at 65 DAS. The highest pod infection found in $\mathrm{T}_{8}$ (Allamanda leaf extract) at 55 and 75 DAS whereas it was found higher in $\mathrm{T}_{9}$ (Lantana leaf extract) at 65 DAS. Among the combined treatments, the highest pod infection was recorded in $\mathrm{T}_{11}(\mathrm{Neem}+$ Rovral) at 55 and 65 DAS but at 75 DAS, it was found higher in $\mathrm{T}_{11}$ (Neem leaf extract + Rovral). From these results it was also revealed that the $\mathrm{T}_{2}$ treatment (Trichoderma harzianum suspension) was gave the moderate result in terms of pod infection (\%) and showed the best performance for controlling grey blight disease of mustard. Almost similar observation was reported by Godika et al. (2001), when they conducted a field experiment to evaluate the efficacy of different chemical fungicides viz. Mancozeb, Ridomil MZ (mancozeb+metalaxyl), Captan, Rovral (iprodione), Bayletan [triadimefon], and Copper oxychloride, against Alternaria blight (Alternaria brassicae) and observed that all the fungicides significantly controlled the disease, but their efficacy varied.

Table 4. Pod infection (\%) under different treatments at 55, 65 and 75 DAS

\begin{tabular}{lccc}
\hline \multirow{2}{*}{ Treatments } & \multicolumn{3}{c}{ Pod infection (\%) } \\
\cline { 2 - 4 } & 55 DAS & 65 DAS & 75 DAS \\
\hline $\mathrm{T}_{1}$ (Control) & $2.97^{\mathrm{a}}$ & $7.25^{\mathrm{a}}$ & $34.63^{\mathrm{a}}$ \\
$\mathrm{T}_{2}$ (Trichoderma harzianum suspension) & $1.31^{\mathrm{bc}}$ & $2.92^{\mathrm{bc}}$ & $19.68^{\mathrm{bc}}$ \\
$\mathrm{T}_{3}$ (Autostin 50 WDG) & $1.14^{\mathrm{bc}}$ & $2.75^{\mathrm{bc}}$ & $17.21 \mathrm{bc}$ \\
$\mathrm{T}_{4}$ (Rovral 50 WP) & $1.02^{\mathrm{bc}}$ & $2.30^{\mathrm{bc}}$ & $12.78^{\mathrm{cd}}$ \\
$\mathrm{T}_{5}$ (Dithane M-45) & $0.65^{\mathrm{c}}$ & $1.73^{\mathrm{c}}$ & $6.72^{\mathrm{d}}$ \\
$\mathrm{T}_{6}$ (Amistar Top 325 SC) & $0.88^{\mathrm{bc}}$ & $1.78^{\mathrm{c}}$ & $9.56^{\mathrm{cd}}$ \\
$\mathrm{T}_{7}$ (Neem leaf extract) & $0.94^{\mathrm{bc}}$ & $3.23^{\mathrm{bc}}$ & $16.85^{\mathrm{bcd}}$ \\
$\mathrm{T}_{8}$ (Allamanda leaf extract) & $1.73^{\mathrm{abc}}$ & $2.79^{\mathrm{bc}}$ & $23.05^{\mathrm{b}}$ \\
$\mathrm{T}_{9}$ (Lantana leaf extract) & $1.18^{\mathrm{bc}}$ & $4.59^{\mathrm{b}}$ & $13.79^{\mathrm{bcd}}$ \\
$\mathrm{T}_{10}$ (Datura leaf extract) & $1.57^{\mathrm{bc}}$ & $3.50^{\mathrm{bc}}$ & $18.55^{\mathrm{bc}}$ \\
$\mathrm{T}_{11}$ (Neem leaf extract+ Rovral) & $1.40^{\mathrm{bc}}$ & $2.53^{\mathrm{bc}}$ & $19.54^{\mathrm{bc}}$ \\
$\mathrm{T}_{12}$ (Datura leaf extract + Amistar Top) & $1.23^{\mathrm{bc}}$ & $2.75^{\mathrm{bc}}$ & $13.82^{\mathrm{bcd}}$ \\
$\mathrm{T}_{13}$ (Lantana leaf extract + Dithane M- 45) & $1.21^{\mathrm{bc}}$ & $2.39^{\mathrm{bc}}$ & $12.30^{\mathrm{cd}}$ \\
$\mathrm{T}_{14}$ (Allamanda leaf extract + Autostin) & $1.96^{\mathrm{ab}}$ & $3.60^{\mathrm{bc}}$ & $17.41^{\mathrm{bc}}$ \\
CV (\%) & $56.25^{\mathrm{bc}}$ & 46.19 & $36.08^{\circ}$ \\
\hline
\end{tabular}

Effect of different treatments on yield and yield contributing parameters in mustard against grey blight disease

The effect on grain yield of mustard under different treatments were summarized and significant variation was found in fresh and dry condition (Table 5). In case of fresh 
weight, among the treatments. the highest grain yield $(1357.3 \mathrm{gm} / \mathrm{plot})$ was recorded in $\mathrm{T}_{13}$ (Lantana + Dithane M-45) followed by $\mathrm{T}_{5}$ (Dithane M-45, $\left.1347.7 \mathrm{gm} / \mathrm{plot}\right)$ and $\mathrm{T}_{9}$ (Lantana leaf extract, $1318.9 \mathrm{gm} / \mathrm{plot}$ ), whereas the lowest yield was found in $\mathrm{T}_{1}$ (Control, $998.4 \mathrm{gm} / \mathrm{plot}$ ). In dry condition, maximum grain yield was obtained in combined treatment $\mathrm{T}_{13}$ (Lantana + Dithane M-45, $1136.3 \mathrm{gm} / \mathrm{plot}$ ), while minimum grain yield was found in $\mathrm{T}_{1}$ (control, $811.7 \mathrm{gm} / \mathrm{plot}$ ). Shrestha et al. (2005) also reported that Mancozeb (Dithane M-45) and Iprodione (Rovral) had effectively reduced grey blight disease in the sprayed plots and increased seed yield by $48 \%$ and $130 \%$, respectively. 1000 -seed weight was significantly affected by grey blight disease of mustard under different treatments. Among the treatments, $\mathrm{T}_{9}$ treatment (Lantana Leaf extract) was gave the best results $(5.16 \mathrm{gm})$ for 1000 -seed weight, which was significantly different from all other treatments. The lowest 1000 - seed

Table 5. Grain yield of Mustard under different treatments

\begin{tabular}{|c|c|c|c|c|}
\hline Treatments & $\begin{array}{l}\text { Fresh wt. } \\
\text { (gm/plot) }\end{array}$ & $\begin{array}{l}\text { Dry wt. } \\
\text { (gm/plot) }\end{array}$ & $\begin{array}{l}1000 \text {-seed } \\
\text { weight }(\mathrm{gm})\end{array}$ & Wt. $\left(\mathrm{t} \mathrm{ha}^{-1}\right)$ \\
\hline $\mathrm{T}_{1}$ (Control) & $998.4^{\mathrm{d}}$ & $811.7^{\mathrm{e}}$ & $3.15^{\mathrm{e}}$ & $1.34^{\mathrm{f}}$ \\
\hline $\begin{array}{l}\mathrm{T}_{2} \text { (Trichoderma harzianum } \\
\text { suspension) }\end{array}$ & 1152.5 & $990.1^{\text {abcde }}$ & $4.55 \mathrm{bc}$ & $1.65^{\text {abcde }}$ \\
\hline $\mathrm{T}_{3}$ (Autostin $\left.50 \mathrm{WDG}\right)$ & $1035.5^{\mathrm{cd}}$ & $905.1^{\mathrm{de}}$ & $4.15^{\mathrm{d}}$ & $1.52^{\mathrm{ef}}$ \\
\hline $\mathrm{T}_{4}($ Rovral $50 \mathrm{WP})$ & $1115.7^{\mathrm{bcd}}$ & $978.4^{\text {bcde }}$ & $4.41 \mathrm{~cd}$ & $1.71^{\text {abcde }}$ \\
\hline $\mathrm{T}_{5}$ (Dithane M-45) & $1347.7^{\mathrm{a}}$ & $1114.7^{\mathrm{ab}}$ & $5.03^{\mathrm{a}}$ & $1.89^{\mathrm{a}}$ \\
\hline $\mathrm{T}_{6}$ (Amistar Top $325 \mathrm{SC}$ ) & $1214.1^{\mathrm{abc}}$ & $1089.1^{\mathrm{abc}}$ & $4.93^{\mathrm{a}}$ & $1.81^{\mathrm{ab}}$ \\
\hline $\mathrm{T}_{7}(\mathrm{Neem}$ leaf extract $)$ & $1028.0^{\mathrm{cd}}$ & $910.4^{\text {cde }}$ & $4.09^{d}$ & $1.56^{\text {cdef }}$ \\
\hline $\mathrm{T}_{8}$ (Allamanda leaf extract) & $1300.0^{\mathrm{ab}}$ & $1122.3^{\mathrm{ab}}$ & $4.92^{\mathrm{a}}$ & $1.78^{\mathrm{abcd}}$ \\
\hline $\mathrm{T}_{9}$ (Lantana leaf extract) & $1318.9^{\mathrm{ab}}$ & $1172.4^{\mathrm{a}}$ & $5.16^{\mathrm{a}}$ & $1.84^{\mathrm{ab}}$ \\
\hline $\mathrm{T}_{10}$ (Datura leaf extract) & $1029.6^{\mathrm{cd}}$ & $969.1^{\text {bcde }}$ & $4.55 \mathrm{bc}$ & $1.62^{\text {bcde }}$ \\
\hline $\mathrm{T}_{11}$ (Neem leaf extract+ Rovral) & $1254.1^{\mathrm{ab}}$ & $1072.8^{\mathrm{abcd}}$ & $4.90^{\mathrm{a}}$ & $1.79^{\mathrm{abc}}$ \\
\hline $\begin{array}{l}\mathrm{T}_{12} \text { (Datura leaf extract }+ \text { Amistar } \\
\text { Top) }\end{array}$ & $1113.9^{\mathrm{bcd}}$ & $996.3^{\text {abcd }}$ & $4.83 \mathrm{ab}$ & $1.54^{\mathrm{def}}$ \\
\hline $\begin{array}{l}T_{13} \text { (Lantana leaf extract + Dithane } \\
M-45)\end{array}$ & $1357.3^{\mathrm{a}}$ & $1136.3^{\mathrm{ab}}$ & $5.00^{\mathrm{a}}$ & $1.86^{\mathrm{ab}}$ \\
\hline $\begin{array}{l}\mathrm{T}_{14} \text { (Allamanda leaf extract }+ \\
\text { Autostin) }\end{array}$ & $1181.6^{\mathrm{abcd}}$ & $910.9^{\text {cde }}$ & $4.26 \mathrm{~cd}$ & $1.5^{\text {ef }}$ \\
\hline CV $(\%)$ & 10.70 & 10.78 & 4.38 & 4.97 \\
\hline
\end{tabular}

weight $(3.15 \mathrm{gm})$ was found in control treatment $\left(\mathrm{T}_{1}\right)$. Results agreed with report by Singh and Singh (2006), they reported that the highest, seed yield and 1000-seed weight under all the dates of sowing were found in two consecutive sprays with 
Mancozeb followed by a third spraying with Ridomil MZ 72 (0.25\%). Among the treatments, the highest yield (1.89 $\left.\mathrm{t} \mathrm{ha}^{-1}\right)$ was recorded in $\mathrm{T}_{5}$ (Dithane M-45) and the lowest yield $\left(1.34 \mathrm{t} \mathrm{ha}^{-1}\right)$ was found in control treatment $\left(\mathrm{T}_{1}\right)$. Results from this study almost similar with report by Godika et al. (2001), they reported that the highest yield of mustard was found in Rovral (2.1 t ha ${ }^{-1}$ ), followed by Mancozeb (Dithane M-45) and Ridomil MZ, each recording a yield of $1.9 \mathrm{t} \mathrm{ha}^{-1}$.

\section{Relationship between grain yield with percent diseases incidence, severity, severity index and pod infection}

Different treatments that were used in the present study regarding grain yield ( $\left.\mathrm{t} \mathrm{ha}^{-1}\right)$ and disease incidence (\%), disease severity (\%), disease severity index (\%) and pod infection (\%). In case of relationship between grain yield $\left(\mathrm{t} \mathrm{ha} \mathrm{ha}^{-1}\right)$ and disease incidence $(\%)$, it was revealed that grain yield was decreased with increased of disease incidence. The highest grain yield $\left(1.89 \mathrm{t} \mathrm{ha}^{-1}\right)$ was found in $\mathrm{T}_{5}$ (Dithane $\mathrm{M}$ 45 ) where the disease incidence was recorded the lowest $(55.91 \%)$ at 70 DAS. On the other hand, the lowest grain yield $\left(1.34 \mathrm{t} \mathrm{ha}^{-1}\right)$ was found while the disease incidence was recorded the highest $(79.20 \%)$ in control treatment $\left(\mathrm{T}_{1}\right)$ at 70 DAS as depicted in the figure 1 . In case of relationship between grain yield $\left(\mathrm{t} \mathrm{ha}^{-1}\right)$ and disease severity $(\%)$, it was revealed that grain yield was decreased with increased of disease severity. The highest grain yield (1.89 $\left.\mathrm{t} \mathrm{ha}^{-1}\right)$ was found in $\mathrm{T}_{5}$ (Dithane M-45) where the disease severity was recorded the lowest (22.09\%) at 70 DAS. On the other hand, the lowest grain yield $\left(1.34 \mathrm{t} \mathrm{ha}^{-1}\right)$ was found while the disease severity was recorded the highest $(37.54 \%)$ in control treatment $\left(\mathrm{T}_{1}\right)$ at 70 DAS as depicted in the figure 2 . In case of relationship between grain yield $\left(\mathrm{t} \mathrm{ha}^{-1}\right)$ and disease severity index $(\%)$, it was revealed that grain yield was decreased with increased of disease severity index. The highest grain yield $\left(1.89 \mathrm{t} \mathrm{ha}^{-1}\right)$ was found in $\mathrm{T}_{5}$ (Dithane M-45) where the disease severity index was recorded the lowest $(32.16 \%)$ at 70 DAS. On the other hand, the lowest grain yield $\left(1.34 \mathrm{t} \mathrm{ha}^{-1}\right)$ was found while the disease severity index was recorded the highest $(67.38 \%)$ in control treatment $\left(\mathrm{T}_{1}\right)$ at 70 DAS as depicted in the figure 3. In case of relationship between grain yield $\left(\mathrm{t} \mathrm{ha}^{-1}\right)$ and pod infection (\%), it was revealed that grain yield and seed quality was decreased with increased of pod infection. The highest grain yield $\left(1.89 \mathrm{tha}^{-1}\right)$ was found in $\mathrm{T}_{5}$ (Dithane M-45) where the pod infection was recorded the lowest $(6.72 \%)$ at 75 DAS. On the other hand, the lowest grain yield $\left(1.34 \mathrm{t} \mathrm{ha}^{-1}\right)$ was found while the pod infection was recorded the highest $(34.63 \%)$ in control treatment $\left(\mathrm{T}_{1}\right)$ at 75 DAS as depicted in the figure 4. Results of relationship study are found to be similar with some previous reports. In a field trial, Howlider et al. (1991) used 5 fungicides (Dithane M-45, Thiovit, Delan, Topsin $\mathrm{M}$ and Cupravit) at 3 doses in controlling Alternaria blight of mustard. Five sprays were applied with first spray at 40 days' growth stage maintaining an interval of 8 days. Dithane M-45 was proved the best with reduction of $73 \%$ in leaf spot severity and siliqua spotting corresponding to obtain an increase of $30 \%$ seed yield. Chattopadhyay and Bagchi (1994) also reported that the severity of leaf blight of mustard, caused by Alternaria brassicae, was negatively correlated with seed yield. 


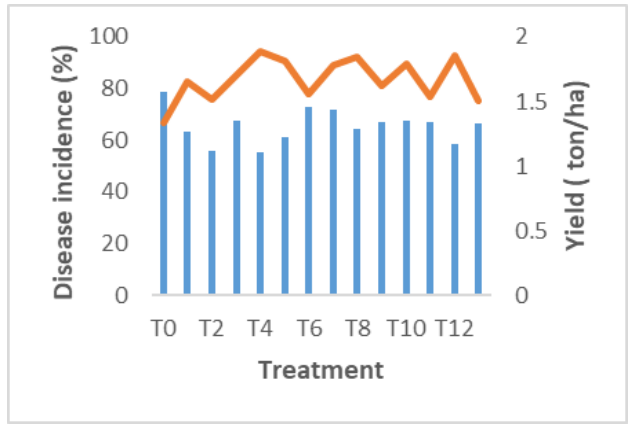

Figure 1. Relationship between disease incidence (\%) at 70 DAS and yield $\left(\mathrm{t} \mathrm{ha}^{-1}\right)$

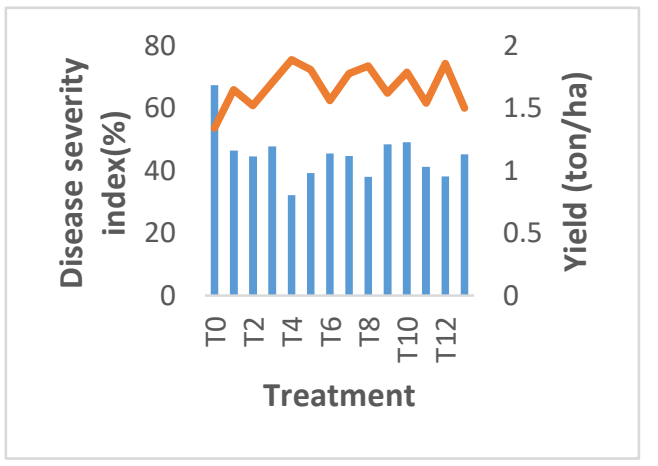

Figure 3. Relationship between disease severity index (\%) at $70 \mathrm{DAS}$ and yield $\left(\mathrm{t} \mathrm{ha}^{-1}\right)$.

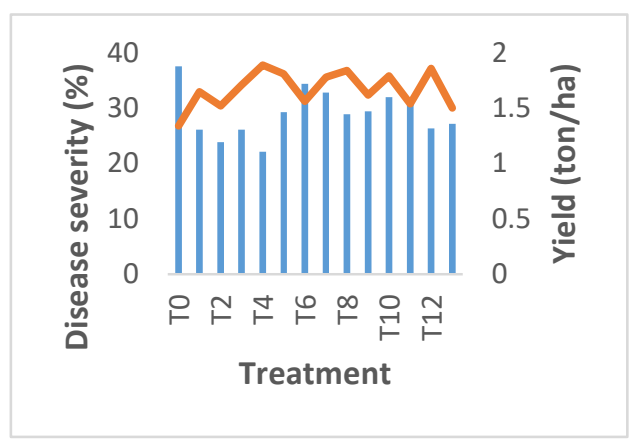

Figure 2. Relationship between disease severity) (\%) at 70 DAS and yield $\left(\mathrm{t} \mathrm{ha}^{-1}\right)$.

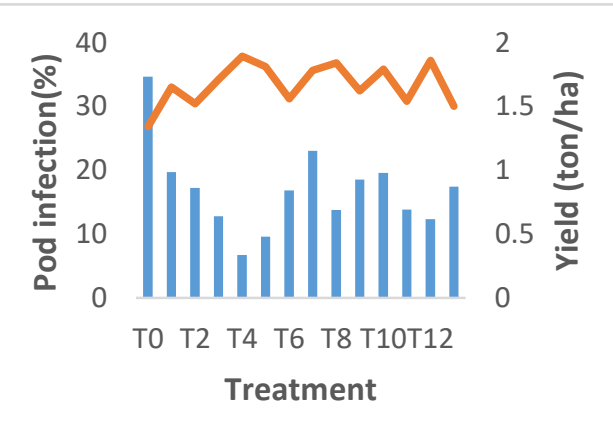

Figure 4. Relationship between pod infections (\%) at 75 DAS and yield $\left(\mathrm{t} \mathrm{ha}^{-1}\right)$.

\section{CONCLUSION}

From the study it may be concluded that among the botanical treatments, lantana leaf extract $\left(\mathrm{T}_{9}\right)$ gave better results and among the chemical fungicides, Dithane M-45 $\left(\mathrm{T}_{5}\right)$ performed the best. In combined effect of the treatments, Lantana leaf extract + Dithane M-45 $\left(T_{13}\right)$ also gave the satisfactory results to manage the grey blight disease of mustard in a field trial. Treatments gave the best result regarding the diseases related parameter also showed better performance in growth promoting characters, yield and yield attributes. From the findings on different parameters studied, the treatment Lantana leaf extract $\left(\mathrm{T}_{9}\right)$, Dithane M-45 $\left(\mathrm{T}_{5}\right)$ and their combined treatment $\left(\mathrm{T}_{13}\right)$ can be used in further field trials and then may be recommended for management of grey blight mustard. 


\section{ACKNOWLEDGEMENT}

Technical assistance from members of Molecular Biology and Plant Virology Laboratory (MBPVL), Department of Plant Pathology and all work forces of Sher-eBangla Agricultural University, Dhaka-1207, Bangladesh, was greatly appreciated. First author also acknowledged to Ministry of Science and Technology for PhD Scholarship.

\section{REFERENCES}

Ahmed, H.U. (1992). Diseases of oilseed crops in Bangladesh. Paper presented in the 2nd Biennial conference of the Bangladesh Phyto-pathological Society.

Alam, K.H.H. (2007). Management of grey blight of mustard through some selected treatments. MS Thesis, Dept. of Plant Pathology, Sher-e-Bangla Agricultural University, Dhaka.

Anonymous. (2001). Production Technology of Oil crops. Oilseed Research Center (ORC), Bangladesh Agricultural Research Institute (BARI), Joydebpur. Pp.4-26.

Anonymous. (2007). Oilseed Crop Diseases and Control. Oilseed Research Center (ORC), Bangladesh Agricultural Research Institute (BARI), Joydebpur. Pp.7.

BBS. (2020). Year Book of Agricultural Statistics of Bangladesh, 2019-20. Statistics Division, Ministry of Planning, Dhaka.

Chattopadhyay, A.K. and Bagchi, B.N. (1994). Relationship of disease severity and yield due to leaf blight of mustard and spray schedule of mancozeb for higher benefit. Journal of Mycopathological Research, 32(2): 83-87.

FAO. (2015). Production for different crops in the world.

Godika, S., Jain, J.P. and Pathak, A.K. (2001). Evaluation of fungitoxicants against Alternaria

blight and white rust diseases of Indian mustard (Brassica juncea). Indian Journal of Agricultural Sciences, 71(7): 497- 49.

Howlider, M.A.R., Meah, M.B., Uddin, M.J. and Rahman, A. (1991). Effect of fungicides on

Alternaria blight, yield and seed quality of mustard. Bangladesh Journal of Agricultural Sciences, 18(1):127-132.

Howlider, M.A.R., Meah, M.B., Uddin, M.J. and Rahman, M.A. (1985). Effect of fungicides in reducing intensity of Alternaria blight of mustard. Bangladesh Journal of Agricultural Sciences, 10(4): 4146.

Meah, M.B., Howlidar, M.A.R., Uddin, M.J. and Rahman, A. (1988). Effect of fungicide spray at different time and frequencies on Alternaria blight of mustard. Thailand Journal of Agricultural Sciences, 21:101-107.

Meena P D, Gupta R, Rani A, Sharma, P. and Singh, D. (2016). Effect of summer temperatures on survival of Alternaria brassicae in infected Indian mustard (Brassica juncea) debris and thermal death point variations amongst geographical isolates. Journal of Oilseed Brassica, 7(1): 45-51. 
Prasad, R., Saxena, D. and Chandra, S. (2003). Yield losses by Alternaria blight in promising genotypes of Indian mustard. Indian Phytopathology, 56(2): 205-206.

Shrestha, L., Munk, and Suresh, B. (2005). Control of Alternaria leaf blight disease caused by Alternaria brassicae in mustard (Brassica juncea). Nepal Agricultural Research Journal, 6: 62-72.

Simmons, E.G. (1992). Alternaria taxonomy: current status, viewpoint, challenge. In: Alternaria biology, plant diseases and metabolites, eds. by J. Chelkowski and A. Visconti, Pp. 1-35. Elsevier Science Publishers, Amsterdam, Netherland.

Singh, R.B. and Singh, R.N. (2006). Spray schedule for the management of Alternaria blight and white rust of Indian mustard (Brassica juncea) under different dates of sowing. Indian Journal of Agricultural Sciences, 76(9): 575-579. 